\title{
Importance of FISH combined with Morphology, Immunophenotype and Cytogenetic Analysis of Childhood/ Adult Acute Lymphoblastic Leukemia in Omani Patients
}

\author{
Tadakal Mallana Goud ${ }^{1 *}$, Kamla Khalfan Al Salmani', Salma Mohammed Al \\ Harasi $^{1}$, Muhanna Al Musalhi², Shah Mohammed Wasifuddin ${ }^{2}$, Anna Rajab ${ }^{1}$
}

\begin{abstract}
Genetic changes associated with acute lymphoblastic leukemia (ALL) provide very important diagnostic and prognostic information with a direct impact on patient management. Detection of chromosome abnormalities by conventional cytogenetics combined with fluorescence in situ hybridization (FISH) play a very significant role in assessing risk stratification. Identification of specific chromosome abnormalities has led to the recognition of genetic subgroups based on reciprocal translocations, deletions and modal number in B or T-cell ALL. In the last twelve years 102 newly diagnosed childhood/adult ALL bone marrow samples were analysed for chromosomal abnormalities with conventional G-banding, and FISH (selected cases) using specific probes in our hospital. G-banded karyotype analysis found clonal numerical and/or structural chromosomal aberrations in $\mathbf{7 4 . 2 \%}$ of cases. Patients with pseudodiploidy represented the most frequent group (38.7\%) followed by high hyperdiploidy group (12.9\%), low hyperdiploidy group $(9.7 \%)$, hypodiploidy $(<46)$ group $(9.7 \%)$ and high hypertriploidy group $(3.2 \%)$. The highest observed numerical chromosomal alteration was high hyperdiploidy (12.9\%) with abnormal karyotypes while abnormal $12 p(7.5 \%)$ was the highest observed structural abnormality followed by $t(12 ; 21)(p 13.3 ; q 22)$ resulting in ETV6/RUNX1 fusion $(5.4 \%)$ and $t(9 ; 22)(q 34.1 ; q 11.2)$ resulting in BCR/ABL1 fusion $(4.3 \%)$. Interestingly, we identified 16 cases with rare and complex structural aberrations. Application of the FISH technique produced major improvements in the sensitivity and accuracy of cytogenetic analysis with ALL patients. In conclusion it confirmed heterogeneity of ALL by identifying various recurrent chromosomal aberrations along with non-specific rearrangements and their association with specific immunophenotypes. This study pool is representative of paediatric/adult ALL patients in Oman.
\end{abstract}

Keywords: Cytogenetics - FISH; prognosis - t(12;21)/ETV6-RUNX1 - 11q23/KMT2A

Asian Pac J Cancer Prev, 16 (16), 7343-7350

\section{Introduction}

Acute lymphoblastic leukemia (ALL) is a heterogeneous form of haematological cancer consisting of various subtypes (Zakaria, 2012). ALL is a malignant disorder of the bone marrow in which lymphoid progenitor cell becomes genetically altered. It is more common in children which represent $80 \%$ of all leukaemia's, whereas in adults accounts only $15 \%$ of leukaemia's (Kebriaei et al., 2003; Pui et al., 2004). The detection of chromosome abnormalities by conventional cytogenetics combined with morphology, immunophenotype and especially with analyses using FISH is an important component in assessing the classification, sub classification, risk stratification and prediction of outcome of ALL patients (Braekeleer et al., 2010).

In acute lymphoblastic leukaemia specific genomic abnormalities provide important clinical information. In most routine clinical diagnostic laboratories conventional karyotyping, in conjunction with targeted screens using e.g., FISH which is currently considered as the gold standard to detect such aberrations (Simons et al., 2011), plays a critical role in guiding targeted therapies, has evolved to become a vital diagnostic tool for personalized medicine (Linping, 2014) and reveal recurring chromosome abnormalities in approximately $80 \%$ of ALL cases, including numerical and structural changes, such as translocations, inversions, or deletions (Harrison et al., 2005; Moorman et al., 2010).

Conventional G-banding is commonly used to detect chromosomal abnormalities (Chang et al., 2006). However, this method has limited use for identification of certain rearrangements such as t(12;21), ETV6/RUNX1 which requires FISH for detection (Romana et al., 1994; Spathas et al 1999). Hence, chromosomal analysis with FISH is more effective in diagnosing certain cryptic translocations (Nordgren et al., 2002), using RT-PCR and interphase- FISH investigated the frequency of 5 fusion

${ }^{1}$ National Genetic Centre, ${ }^{2}$ Division of Oncology, Royal Hospital, Ministry of Health, Muscat, Sultanate of Oman *For correspondence:tmgoud99@gmail.com 
oncogenes in adult ALL patients, and their association with clinical features, treatment response and outcome (Sabir et al., 2012). FISH was used as a complementary method in this study for some ALL patients to reconfirm cytogenetic findings and also those poor quality samples. The combination of both methods can improve the detection rate of genetic abnormalities in childhood leukaemia. Increasing knowledge of the cytogenetic classification of this disease contributes to important prognostic information for treatment planning.

Here we present the cytogenetic pattern of 102 Omani ALL patients and their correlation with other prognostic factors studied at the National Genetic Centre in Oman. The aim of the present study was to define the frequency and types of acquired chromosomal aberrations in Omani patients with ALL using FISH technique, and to compare this data set with those reported in the literature.

\section{Materials and Methods}

\section{Patients}

Cytogenetic studies were performed on 102 cases of newly diagnosed ALL cases from the paediatric and adult haematology / oncology department, Royal hospital were referred to our cytogenetics laboratory, at the National Genetic Centre, Ministry Of Health, Oman between Jan-2002 and Dec-2013. Bone marrow cultures for nine patients of the 102 either yielded no metaphases or the quality of the chromosomes was too poor with clumped metaphases to allow a feasible identification of the chromosomes. All failures occurred among patients with ALL analysed at diagnosis. The remaining 93 patients were investigated in this study, of these 71 were children and 22 were adults. The diagnosis of ALL was based on morphologic classification, immunophenotyping of French American-British classification (FAB) (Bennet et al., 1976) and karyotyping.

\section{Conventional Cytogenetics}

Bone marrow samples were cultured for 24-48 hrs in RPMI-1640 (GIBCO BRL, USA) containing 20\% foetal bovine serum (GIBCO BRL) and antibiotics, after which the trypsin-giemsa banding technique was used to analyse and categorize the chromosomes of 20 metaphase cells according to the International System for Human Cytogenetic Nomenclature (ISCN 2013). It was necessary for an abnormal clone to identify two abnormal metaphase cells with the cases of structural abnormalities or hyperdiploidies, and at least three abnormal metaphase cells for hypodiploidies. Numerical abnormalities were classified as low hyperdiploid with 47-50 chromosomes, high hyperdiploid with 47-57 chromosomes, pseudodiploid (46 chromosomes with structural or numerical abnormalities), diploid (normal 46 chromosomes), and hypodiploid (35-45 chromosomes).

\section{Immunophenotyping in the diagnosis and classification} of $A L L$

The lineage of most cases of morphologically and cytochemically poorly differentiated ALL's can be accurately characterized by immuno $\neg$ phenotyping (Salem and Abd El-Aziz, 2012). Flow Cytometry was used to confirm the blast Immunophenotype using a TdT assay and a panel of monoclonal antibodies (Mo Abs) to T cell and $\mathrm{B}$ cell associated antigens were used to identify almost all cases of ALL (Jennings and Foon, 1997).

\section{Fluorescent in situ hybridization}

In methods similar to the chromosomal analysis, bone marrow cells were cultured for 24-48hrs after which slides were prepared and hybridization was done using available probes in selected cases, and only for the recent cases FISH ALL panel probes were applied. The following probes were used in our experiment: LSI BCR/ABL Dual Colour Translocation Probe (Vysis), LSI ETV6/RUNX1 Dual Colour Translocation Probe (Vysis), LSI KMT2A (ALL-1, HRX) Dual Colour Break Apart Rearrangement Probe (Vysis), PBX/E2A (TCF3) Dual Colour and LSI MYC \& BCL6 (Vysis) Dual Colour and so on.

The hybridizations were performed on fixed cell pellets after cytogenetic analysis. Cells were counter stained with DAPI (4, 6- diamidino 2-phenylindole), then were examined with a fluorescent microscope equipped with appropriate filters and metasystem FISH system image capture software (ZiessAxioskop 2 plus) and at least 50 metaphase cells and 100 interphase nuclei were analysed (depending on the mitotic index) using fluorescent microscope to detect translocations and deletions/ rearrangements.

\section{Results}

Ninety-three newly diagnosed ALL patients were included in the study, all of whom underwent chromosomal analysis. Of the 93, 54 (58\%) were male and 39 (42\%) were female. An abnormal karyotype pattern was noted for $69(74.2 \%)$ individuals. The incidence was significantly higher in males $(58 \%)$ than in females $(42 \%)$. The median age of children at diagnosis was 5.7 years (range 0.7 to 12 years) and Median age of Adult ALL patients at diagnosis was 17.5 years (range 13 to 22 years), only 4 patients were $\sim 60$ years. The median Haemoglobin level at diagnosis was $9.7 \mathrm{~g} / \mathrm{dl}$ (range 5.1 to 15.1 ); the median WBC count at diagnosis was $79.73 \times 109 / \mathrm{L}$ (range 1.3 to 720). The majority had $72(78 \%)$ thrombocytopenia and presented with platelet count less than $(130 \mathrm{X} 109 / \mathrm{L})$. Immunophenotypically, 40 (43\%) patients were classified as precursor B ALL, 19 (21\%) were B cell ALL, 24 (26\%) T cell ALL, 2 (2\%) were biphenotypic leukaemia, 3 (3\%) were Null [non B, non T], and $5(5 \%)$ were not done. Morphologically, $46(50 \%)$ patients were classified as FAB L1, 42 (45\%) patients were classified as FAB L2, 3 (3\%) patients were classified as FAB L3, and data on two cases were not available (Table 1).

\section{Cytogenetic Findings}

An abnormal karyotype was noted in 69 patients $(74.2 \%)$ with either numerical or structural, or both abnormalities combined. Twenty five $(26.9 \%)$ patients showed numerical abnormalities only, Thirty six (38.7\%) patients showed structural abnormalities only, eight (8.6\%) patients showed both (Table 1). 
Numerical chromosome abnormalities at diagnosis

The distribution by modal number of the 93 patients with successful analysis at diagnosis is shown in Figure 1. Of 93 patients 24 (25.8\%) had apparently normal diploid karyotypes. Chromosome abnormalities were observed in samples from 69 patients $(74.2 \%)$. Patients with pseudodiploidy represented the most frequent group 36/93 (38.7\%) followed by high hyperdiploidy $(<69$ chromosomes) 12/93 (12.9\%), low hyperdiploidy (47-50 chromosomes) $9 / 93(9.7 \%)$, hypodiploidy (35-45) group 9/93 (9.7\%) and high hypertriploidy (70-75 chromosomes) $3 / 93$ (3.2\%) (Figure1). The most common addition was chromosome 21 and marker chromosome, followed by chromosomes 6, 4, 17, 2, 14, 10, 18, 22, 11, 14 5, 8 and 19. Chromosomal loss was most commonly seen with the 9 chromosome, followed by $7,8,13,14,5,6$, and 18 (Figure 2).

One case with mosaic cell line high hypertriploid/near tetraploid with i(17q) FISH analysis shows Frequently associated with ETV6/RUNX1 fusion, each with 4 signals of ABL/BCR, KMT2A, ETV6/RUNX1, Tetraploid $(90<4 n>, X X, X Y)$ are rare but recurrent in B-ALL. Another hyperdiploid patient mosaic karyotype showed 47-50, XX, +X, -8, +9, +10, +16, +18, +21, [12]/46, XX[18], FISH supernumerary RUNX1 signal in $63 \%$ cells corresponding to acquired trisomy 21 , sole clonal abnormity +21 accounts for $<5 \%$ of childhood ALL with favourable prognosis.

One hypodiploid patient with combined structural

Table 1.Clinical and Hematopathological Characteristics of 93 ALL Patients

\begin{tabular}{|c|c|c|}
\hline \multicolumn{3}{|l|}{$\overline{\text { Sex }}$} \\
\hline Male & 54 & $58 \%$ \\
\hline Female & 39 & $42 \%$ \\
\hline \multicolumn{3}{|l|}{ Age (year) } \\
\hline $1-5$ years & 38 & $41 \%$ \\
\hline $6-9$ years & 15 & $16 \%$ \\
\hline $10-14$ years & 18 & $19 \%$ \\
\hline 15 - 18 years & 8 & $9 \%$ \\
\hline 19 - 22 years & 10 & $11 \%$ \\
\hline$\sim 60$ years & 4 & $4 \%$ \\
\hline \multicolumn{3}{|l|}{ WBC Count (x109/1) } \\
\hline$<20$ & 57 & $61 \%$ \\
\hline $20-100$ & 15 & $16 \%$ \\
\hline$\geq 100$ & 21 & $23 \%$ \\
\hline \multicolumn{3}{|l|}{ FAB Morphology } \\
\hline L1 & 46 & $50 \%$ \\
\hline L2 & 42 & $45 \%$ \\
\hline L3 & 3 & $3 \%$ \\
\hline Not done & 2 & $2 \%$ \\
\hline \multicolumn{3}{|l|}{ Immunophenotype } \\
\hline Pre B Cell & 40 & $43 \%$ \\
\hline B Cell & 19 & $21 \%$ \\
\hline T Cell & 24 & $26 \%$ \\
\hline Bi-phenotype & 2 & $2 \%$ \\
\hline Null (non B, non T) & 3 & $3 \%$ \\
\hline ND (not done) & 5 & $5 \%$ \\
\hline \multicolumn{3}{|l|}{ Types of Cytogenetic abnormalities } \\
\hline Normal & 24 & $25.80 \%$ \\
\hline Numerical abnormalities & 25 & $26.90 \%$ \\
\hline Structural abnormalities & 36 & $38.70 \%$ \\
\hline Both Abnormalities Combined & 8 & $8.60 \%$ \\
\hline
\end{tabular}

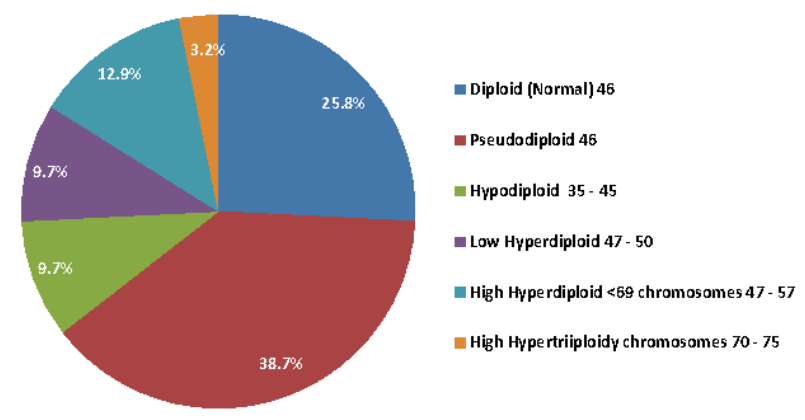

Figure 1. Numerical Abnormalities $(n=93)$ in all 5 Ploidy Cases or Distinguished

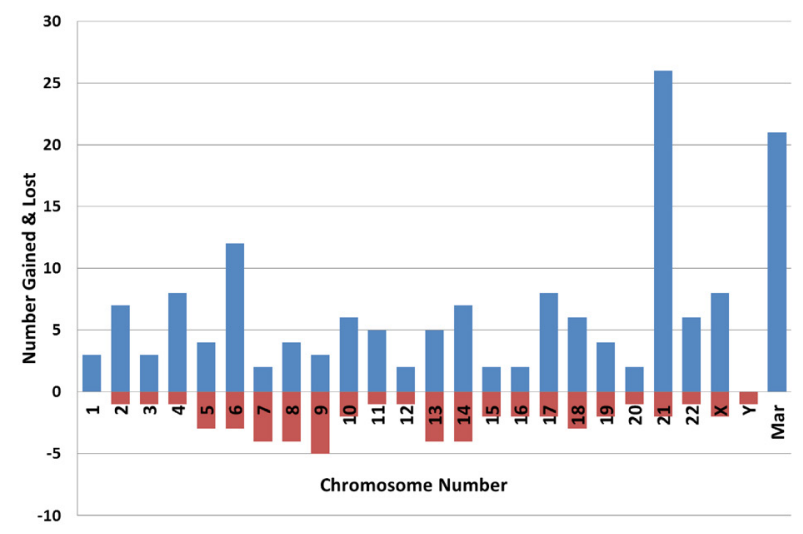

Figure 2. Gain and Loss of Chromosome

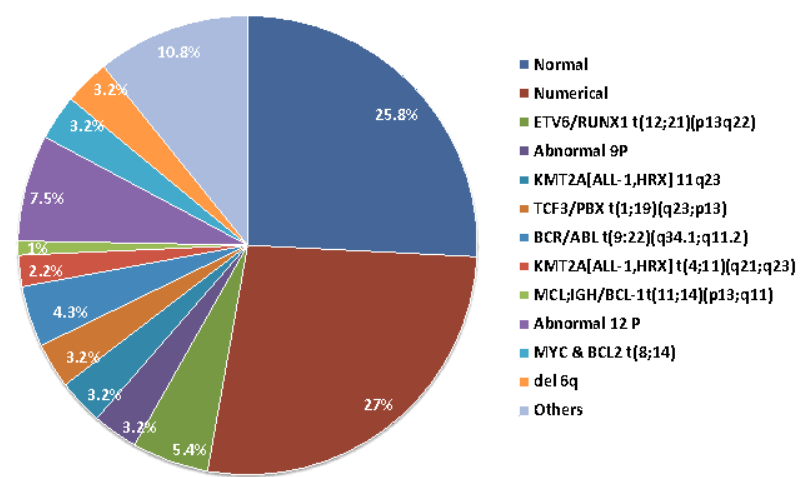

Figure 3. Distribution of Patients with Structural Abnormalities in ALL Patients

abnormality had 45, XY, t(1;19)(q23;p13), del(6)(q1314), $-13, \mathrm{E} 2 \mathrm{~A} / \mathrm{PBX} 1$ which portends a poor prognosis.

\section{Structural Abnormalities}

Evaluation of abnormal karyotypes indicated structural abnormalities in $44(47.3 \%)$ patients and 25 (26.9\%) had only numerical aberrations. Recurrent structural abnormalities were detected in 24 cases (26\%). Amongst the structural abnormalities that are closely related to prognosis, abnormal $12 \mathrm{p}$ was found in $7(7.5 \%)$ out of 93 patients, $\mathrm{t}(12 ; 21)(\mathrm{p} 13.3 ; \mathrm{q} 22) \mathrm{ETV} 6 / \mathrm{RUNX} 1$ was found in $5(5.4 \%)$ patients, KMT2A 11q23 abnormalities in 3 (3.2\%) cases, KMT2A[ALL-1/HRX] t(4;11)(q21;q23) found in $2(2.2 \%)$ cases, $t(8 ; 14)(\mathrm{q} 24 ; \mathrm{q} 32)$, MYC/BCL6 in $3(3.2 \%)$ ALL L3 Burkitt's leukemia/lymphoma patients, other recurrent structural rearrangements detected were $\operatorname{del}(6 q)$ found in $3(3.2 \%)$ cases and abnormal (9p) found in $3(3.2 \%)$ patients, $\mathrm{t}(1 ; 19)(\mathrm{q} 23 ; \mathrm{p} 13.3)$, E2A/PBX1 in $3(3.2 \%)$ patients, $\mathrm{t}(9 ; 22)(\mathrm{q} 34.1 ; \mathrm{q} 11.2), \mathrm{BCR} / \mathrm{ABL}$ in 4 
Tadakal Mallana Goud et al

Table 2. Details of Patients with Nonspecific Structural Chromosomal Abnormalities

\begin{tabular}{|c|c|c|c|c|c|c|c|c|}
\hline $\begin{array}{l}\text { Case } \\
\text { No. }\end{array}$ & $\begin{array}{l}\text { Sex/ } \\
\text { Age } \\
(\mathrm{Yr})\end{array}$ & $\begin{array}{l}\text { WBC } \\
\left(\times 10^{9}\right. \\
/ L)\end{array}$ & FAB & Immunophenotype (IP) & $\begin{array}{l}\text { IP } \\
\text { diag- } \\
\text { nosis }\end{array}$ & $\begin{array}{c}\text { Chromosomal } \\
\text { Abnormality/ } \\
\text { Cytogenetic-Findings }\end{array}$ & FISH & $\begin{array}{l}\text { Out } \\
\text { Come }\end{array}$ \\
\hline $958 / 01$ & $\mathrm{M} / 12$ & 7.45 & L2 & $\begin{array}{l}\text { CD4+CYT3+CD5+ } \\
\text { CD7+CD8+CD10+ } \\
\text { CD34-CD45+Tdt+ }\end{array}$ & T ALL & $\begin{array}{l}42, X Y, \operatorname{del}(5) \\
(\mathrm{p} 11),-9,-17,-20, \\
-21,-22,+1 \text { mar. }\end{array}$ & Not done & $\begin{array}{l}\text { complete } \\
\text { remission } \\
\text { then } \\
\text { relapse } \\
\text { after } 1 \\
\text { year in } \\
\text { BM \& } \\
\text { CNS }\end{array}$ \\
\hline $972 / 01$ & $\mathrm{~F} / 13$ & 12.5 & L1 & $\begin{array}{c}\mathrm{CD} 2+\mathrm{CD} 3+\mathrm{CD} 4+ \\
\mathrm{CD} 6+\mathrm{CD} 7+\mathrm{CD} 8+ \\
\mathrm{CD} 10+\mathrm{Tdt}+\mathrm{Ia}\end{array}$ & $\begin{array}{l}\text { Pre B } \\
\text { ALL }\end{array}$ & $\begin{array}{c}46, \mathrm{XXt}(3 ; 12)(\mathrm{q} 29 ; \mathrm{p} 12), \\
-5,-8,-9,+12 \\
\text { del }(17)(\mathrm{p} 12) \\
\text { add(18p), } \\
+2 \text { mar. ALL'S } \\
\end{array}$ & Not done & $\begin{array}{l}\text { Lost to } \\
\text { Follow- } \\
\text { up }\end{array}$ \\
\hline $1855 / 02$ & $\mathrm{M} / 10$ & 45.5 & L1 & $\begin{array}{c}\mathrm{CD} 2 \mathrm{~W}+\mathrm{CyCD} 3+\mathrm{CD} 1 \mathrm{a}+ \\
\text { heteroCD5W+CD7+ } \\
\text { Cells with dualCD4+ } \\
\text { CD8+ indicating T } \\
\text { Lymphoproliferation, } \\
\text { however TdT-CD79a+ } \\
\text { (earliest indicator for T } \\
\text { ALL) }\end{array}$ & T ALL & $\begin{array}{l}\text { 46,XY,add }(4)(\mathrm{p} 15) \\
\text { inv }(6)(\mathrm{p} 21.3 \mathrm{q} 15) \\
\text {-13,,-14,del(14q), } \\
\text { +2 mar/46,XY. }\end{array}$ & Not done & Alive \\
\hline $3469 / 05$ & $\begin{array}{l}\mathrm{M} / \\
0.7\end{array}$ & 21.2 & L2 & $\begin{array}{c}\text { CD10+CD19+ } \\
\text { cytoplasmic } \\
\text { CD22+79a+with dim } \\
\text { expression of } \\
\text { cytoplasmic mu(Igm) }\end{array}$ & $\begin{array}{l}\text { Pre B } \\
\text { ALL }\end{array}$ & $\begin{array}{c}\text { 46,XY,t }(\mathrm{X} ; 6)(\mathrm{p} 22 ; \mathrm{q} 23) \\
\mathrm{t}(5 ; 11)(\mathrm{q} 13 ; \mathrm{p} 12) \\
\text { ALL L1/L2 }\end{array}$ & Not done & Died \\
\hline $4315 / 07$ & $\mathrm{M} / 11$ & 1.8 & L2 & $\begin{array}{c}\text { CD19+CD20+CD79a+ } \\
\text { CD10+TdT+CD34+ }\end{array}$ & $\begin{array}{c}\text { B- } \\
\text { ALL }\end{array}$ & $\begin{array}{c}59, \mathrm{XY},+1,+2,+4, \\
+6,+8,+11,+13, \\
+15,+17,+\mathrm{i}(17 \mathrm{q}),+18, \\
+21\{2\} .90<4 \mathrm{n}>, \mathrm{XX}, \mathrm{XY}, \\
-7, \mathrm{i} 17 \mathrm{q}\{14\} / 46, \mathrm{XY}\{14\}\end{array}$ & $\begin{array}{c}\text { Frequently } \\
\text { associated } \\
\text { with ETV6/RUNX1 } \\
\text { fusion, } \\
\text { each with } 4 \\
\text { signals of ABL/ } \\
\text { BCR,KMT2A, } \\
\text { ETV6/RUNX1, }\end{array}$ & $\begin{array}{l}\text { Lost to } \\
\text { Follow- } \\
\text { up }\end{array}$ \\
\hline $5212 / 08$ & $\mathrm{M} / 8$ & 55.5 & L1 & $\begin{array}{l}\text { CD19+CD10+CD79a+ } \\
\text { TdT+Cmute with aberrant } \\
\text { expression of CD13 }\end{array}$ & $\begin{array}{c}\text { Pre B } \\
\text { Cell } \\
\text { ALL }\end{array}$ & $\begin{array}{c}\text { 46,XY,t(12;17) } \\
(\mathrm{p} 13 ; \mathrm{q} 21)\{20\} / 46, \\
\mathrm{XY}\{5\}\end{array}$ & $\begin{array}{c}\text { Ish t }(12 ; 17) \\
\text { (WCP17+, } \\
\text { ETV6+,WCP17+, } \\
\text { ETV6-) } \\
\text { confirms t }(12 ; 17) .\end{array}$ & $\begin{array}{l}\text { Lost to } \\
\text { Follow- } \\
\text { up }\end{array}$ \\
\hline $5227 / 08$ & $\mathrm{~F} / 20$ & 50.2 & L1 & $\begin{array}{c}\mathrm{CD} 2+\mathrm{CD} 3+\mathrm{CD} 5+ \\
\mathrm{CD} 7+\end{array}$ & $\begin{array}{l}\text { T Cell } \\
\text { ALL }\end{array}$ & $\begin{array}{c}45, X X, t(9 ; 15) \\
(\mathrm{p} 21-22 ; \mathrm{q} 11-13) \\
\{8\} / 46, X X\{22\end{array}$ & Not done & Alive \\
\hline $5559 / 08$ & $\mathrm{M} / 14$ & 3.8 & L2 & $\begin{array}{l}\text { CD2+CD3-CD4+ } \\
\text { CD5+CD7+CD34+, } \\
\text { CD19-CD20- }\end{array}$ & $\begin{array}{l}\text { Prec- } \\
\text { ursor } \\
\text { T Cell } \\
\text { ALL }\end{array}$ & $\begin{array}{c}\text { 46,XY,del }(5) \\
(\mathrm{q} 21 \mathrm{q} 24)(6) / 46, \\
\text { XY(16).interstial } \\
\text { deletion of } \\
\text { long arm of } 5,\end{array}$ & $\begin{array}{c}\text { EGR 1 }(5 \mathrm{q} 31) / \\
\text { D5S23, } \\
\text { D5S721 }(5 \mathrm{p} 15), \\
\text { EGR 1 } \\
\text { deletion in } 98 \% \text { of } \\
\text { cells. }\end{array}$ & Alive \\
\hline $5601 / 08$ & $\mathrm{M} / 11$ & 648 & L1 & $\begin{array}{c}\mathrm{CD} 2+\mathrm{CD} 5+\mathrm{CD} 7+ \\
\mathrm{cCD} 3+\end{array}$ & $\begin{array}{l}\text { T Cell } \\
\text { ALL }\end{array}$ & $\begin{array}{c}46, X Y, t(8 ; 12) \\
(p 21 ; q 13) \\
\{3\} / 46, X Y\{37 .\end{array}$ & $\begin{array}{l}\text { Fish no fusion BCR/ } \\
\text { ABL \& No KMT2A } \\
\text { rearrangements }\end{array}$ & Alive \\
\hline $6906 / 10$ & $\mathrm{M} / 2$ & 18.8 & L1 & $\begin{array}{c}\text { TdT+ve,CD10+, } \\
\text { CD19+,Cmu+ }\end{array}$ & $\begin{array}{l}\text { Pre B } \\
\text { ALL }\end{array}$ & $\begin{array}{c}46, X Y, \\
\text { der }(18)(12 ; 18) \\
(q 12 ; p 11)\{14\} / \\
46, X Y\{6\}\end{array}$ & Not done & Alive \\
\hline
\end{tabular}

(4.3\%) patients, one patient had MCL;IGH/BCL1 t $(11 ; 14)$ (p13;q11) which is rarely reported (Figure 3), and the nonspecific structural chromosomal aberrations were detected in 16 cases (details are listed in Table 2).

Conventional Chromosomal Analysis and FISH

A total of only 24 patients were studied at diagnosis by
FISH. Of these, two patients showed a normal karyotype but were found to have $\mathrm{t}(12 ; 21)(\mathrm{p} 13.3 ; \mathrm{q} 22)$, ETV6/ RUNX1 rearrangement which is never identifiable by conventional cytogenetics were detected by FISH. One 2 yrs old child reported with 46, XY, der(18)(12;18) (q12;p11)\{14\}/46, XY\{6\} FISH analysis showed ETV6/

7346 Asian Pacific Journal of Cancer Prevention, Vol 16, 2015 
Table 2 (continued). Details of Patients with Nonspecific Structural Chromosomal Abnormalities

\begin{tabular}{|c|c|c|c|c|c|c|c|c|}
\hline $\begin{array}{l}\text { Case } \\
\text { No. }\end{array}$ & $\begin{array}{l}\mathrm{Sex} / \\
\text { Age } \\
(\mathrm{Yr})\end{array}$ & $\begin{array}{c}\text { WBC } \\
\left(\times 10^{9}\right. \\
/ \mathrm{L}) \\
\end{array}$ & FAB & Immunophenotype (IP) & $\begin{array}{c}\text { IP } \\
\text { diag- } \\
\text { nosis }\end{array}$ & $\begin{array}{c}\text { Chromosomal } \\
\text { Abnormality/ } \\
\text { Cytogenetic-Findings }\end{array}$ & FISH & $\begin{array}{l}\text { Out } \\
\text { Come }\end{array}$ \\
\hline $7055 / 10$ & $\mathrm{~F} / 10$ & 2.7 & $\mathrm{~L} 1$ & $\begin{array}{c}\text { CD9+CD10+CD19+ } \\
\text { CD34+cCD79a+ }\end{array}$ & $\begin{array}{l}\text { B Cell } \\
\text { ALL }\end{array}$ & $\begin{array}{c}46-48, \mathrm{XX}, \\
\operatorname{add}(5)(\mathrm{p} 1 ? 4) \\
\operatorname{add}(17)(\mathrm{q} 24),+21, \\
+21[\mathrm{cp} 6] 88-98,<\mathrm{n}>, \\
\text { XXXX, slx } 2,-2,-3,+11,+2, \\
3 \operatorname{mar}[\mathrm{cp} 14] \\
/ 46, \mathrm{XX}[5],\end{array}$ & $\begin{array}{c}\text { Near Tetraploidy } \\
\text { makes up fewer } \\
\text { tha1\% } \\
\text { of childhood ALL } \\
\text { cases \& been } \\
\text { associated-poorer } \\
\text { prognosis. FISH } 4 \\
\text { \& } 5 \text { KMT2A signals, } \\
\text { 2 ETV6 \& } 4 \\
\text { RUNX1 signals. } \\
\text { pseudodiploidy/tetra } \\
\text { ploidy } \\
\end{array}$ & $\underset{\text { remission }}{\text { In }}$ \\
\hline $7215 / 10$ & $\mathrm{M} / 26$ & 42.5 & L1 & $\begin{array}{c}\text { CD19+, cCD79a+, } \\
\text { cMute+ } \\
\& \text { CD+. Also CD34+, } \\
\text { CD33+,HLA-DR+, } \\
\text { CD13+ and dimTdT. }\end{array}$ & $\begin{array}{l}\text { Pre B } \\
\text { ALL }\end{array}$ & $\begin{array}{c}\text { 46-47,XY,t(2;?11) } \\
(\mathrm{p} 12 ? \mathrm{p} 15), \\
\operatorname{add}(12)(\mathrm{p} 13), \\
+\operatorname{mar}[8] / 46, \\
\text { XY[18]. complex } \\
\text { rearrangement, } \\
\text { bal } \mathrm{t}(2 ; 11), \\
\text { addnl material on } 12 \mathrm{p} \\
\text { \& } 1 \text { mar. Confirm } \\
\text { by FISH }\end{array}$ & $\begin{array}{c}\text { 46,XY,t(2;11) } \\
\text { (p12;p12), } \\
\mathrm{t}(2 ; 12)(\mathrm{p} 12 ; \mathrm{p} 13) \\
\text { ish t(2;11)(WCP2+, } \\
\text { WCP11+,2pter- } \\
, 11 \text { pter+, }\end{array}$ & $\begin{array}{l}\text { In remis- } \\
\text { sion }\end{array}$ \\
\hline $7354 / 10$ & $\mathrm{~F} / 3$ & 498 & L1 & $\begin{array}{c}\text { CD9+CD10+CD19+ } \\
\text { CD20+CD22+CD34+ } \\
\text { TdT+HLA-DR+Cytomu+ }\end{array}$ & $\begin{array}{l}\text { Pre B } \\
\text { ALL }\end{array}$ & $\begin{array}{c}\text { 46,XX,t(7;9) } \\
\text { (q11;p13) } \\
\text { clonal abnormality }\end{array}$ & $\begin{array}{l}\text { ALL FISH panel } \\
\text { probes showed } \\
\text { a Normal signal } \\
\text { pattern }\end{array}$ & $\begin{array}{l}\text { no } \\
\text { relapse, } \\
\text { ALL in } \\
\text { remission } \\
\text { by MRD }\end{array}$ \\
\hline $7375 / 10$ & $\mathrm{~F} / 8$ & 282 & L1 & $\begin{array}{c}\mathrm{CD} 2+\mathrm{CD} 3+\mathrm{CD} 5+ \\
\mathrm{CD} 7+\mathrm{CD} 9+\mathrm{CD} 34+ \\
\mathrm{CD} 56+, \mathrm{CD} 117+\mathrm{TdT}+\end{array}$ & ? ALL & $\begin{array}{l}46, X X, t(11 ; 17) \\
\text { (q23;q12-21). }\end{array}$ & $\begin{array}{l}\text { ALL FISH panel } \\
\text { probes showed } \\
\text { a Normal signal } \\
\text { pattern }\end{array}$ & $\begin{array}{l}\text { In remis- } \\
\text { sion }\end{array}$ \\
\hline $7919 / 11$ & $\mathrm{~F} / 10$ & 2.6 & BL & $\begin{array}{c}\mathrm{CD} 2+\mathrm{CD} 3+\mathrm{CD} 5+ \\
\mathrm{CD} 7+\mathrm{CD} 9+\mathrm{CD} 13+, \\
\text { CD33+,CD34+,CD117+, } \\
\text { HLA-DR+, }\end{array}$ & BL & $\begin{array}{c}\text { 47,XX,del(20)(p12), } \\
\operatorname{del}(9)(\mathrm{q} 21-22),-14,+21, \\
+\operatorname{mar}[9] / 47, \mathrm{XX}, \\
\operatorname{del}(2)(,-5, \mathrm{p} 12), \\
\operatorname{del}(9)(\mathrm{q} 21-22),+10, \\
-14, \operatorname{del}(16)(\mathrm{q} 22),+21, \\
+\operatorname{mar}[8] / 46, \\
\mathrm{XX}[3] .\end{array}$ & Not done & Died \\
\hline $8052 / 11$ & $F / 3$ & 9.36 & L1 & $\begin{array}{c}\mathrm{CD} 3+(71 \%), \mathrm{CD} 7+(98 \%) \\
\text { except } \mathrm{CD} 5, \mathrm{CD} 4 \& \mathrm{CD} 8 \\
<10 \%\end{array}$ & $\begin{array}{l}\text { T Cell } \\
\text { ALL }\end{array}$ & $\begin{array}{l}46, \mathrm{XX}, \mathrm{t}(2 ; ; 5 ; 11) \\
(\mathrm{q} 34 ; \mathrm{q} 13 ; \mathrm{q} 1),\end{array}$ & $\begin{array}{c}\text { FISH } 46, \mathrm{XX} \text { ish } \\
\text { der(5)t }(5 ; 11) \\
\text { (q13;q13), deteted a } \\
\text { copy of gene } 11 \mathrm{q} 23 \\
\text { transl to } 5 \mathrm{q} 13 \\
\text { confirming } \mathrm{t}(5 ; 11) \\
\quad(\mathrm{q} 13 ; \mathrm{q} 13)\end{array}$ & Died \\
\hline
\end{tabular}

BL, biphenotypic leukemia

RUNX1 fusion in $95 \%$ of the nuclei analysed, molecular equivalent of the cryptic translocation(12;21)(p13.3;q22). A ETV6 deletion at one chromosome correspond to unbalanced $\mathrm{t}(12 ; 18)$ leading to monosomy $12 \mathrm{p}$, another 4 years old child karyotype showed deletion at $12 \mathrm{p}$ but, FISH detected ETV6/RUNX1 loci in the $t(12 ; 21)$ (p13.3;q22). Another case karyotype was 46, XX, der(8) $\mathrm{t}(8 ; ?)(\mathrm{p} 22 ; ?),-12, \operatorname{der}(21) \mathrm{t}(12 ; 21)(\mathrm{p} 12 ; \mathrm{q} 22) \times 2,+21[5] / 46$, $\mathrm{XX}$ [13]-chromosome $(12 \& 21 \mathrm{q}$ associated with an additional chromosome abnormality of $8 \mathrm{p}$ revealed the involvement of ETV6-RUNX1 loci in the t(12;21) (74\% cells) was confirmed by FISH. The remaining FISH analysis cases showed in Figure 3 and Table 2.

\section{Discussion}

This study determined the frequency and type of acquired chromosomal aberrations in ALL Omani patients. The results of cytogenetic, morphologic, immunophenotyping and FISH tests can help provide information on types and subtypes of ALL cells. The particular subtype of cell can aid in determining prognosis and treatment. In this study, $74 \%$ of ALL cases are children and only $26 \%$ are adults. Chromosome abnormalities were identified in $69(74.2 \%)$ patients out of a study group of 102 individuals. In the literature, clonal structural or numerical chromosome abnormalities are reported in 80- 
$90 \%$ of paediatric cases and in $70 \%$ of adult cases (Ferrando and Look 2000; Harrison 2001; Kebriaei et al., 2003; Mroz'ek 2004; Braekeleer et al., 2010). The incidence is unevenly distributed across age and ethnic groups (Mroz'ek 2004; Johansson 2009). Especially, B-lineage ALL is more frequent, accounting for $85 \%$ of childhood ALL and $75 \%$ of adult ALL (WHO, 2008). However, the incidence of chromosomal abnormalities was higher than previously reported studies (Foristier et al., 1997; Mehdipour et al., 2003; Gimidene et al 2008), similar results (Perez-Vera et al., 2001; Al-Bahar et al., 2010) and lower than some studies (Chang et al., 2006; Kwon et al., 2009; Braekeleer et al., 2010). In our study, the bone marrow cultures for nine patients either yielded no metaphases or the quality of the chromosomes was too poor with clumped metaphases, which is commonly known in most of the ALL cases (Petkovic et al., 1996) and the percentage of diploid karyotype $(25.8 \%)$ presently tended to decrease compared to the earlier years, likely attributable to technical progress such as improvement of culture conditions, cell synchronization, and the introduction of integrated FISH screening method may have led to a higher incidence rate of chromosomal abnormalities in our study similar to previous studies (Hashem, 2012). The presence of normal metaphases could be explained as residual normal cells, the marrow infiltration by leukemic blasts being usually partial; it could also be the result of the low mitotic rate of the blast cells (Harrison and Faroni, 2002).

According to the ploidy (Figure1), the incidence and the biological characteristics of hyperdiploid ALL cases were similar to those described in the literature.In our study the frequency of hyperdiploidy (nearly 22.6\%) which comprises Low hyperdiploid $(9.7 \%)$, High hyperdiploid $(12.9 \%)$ and differed from that previously reported which has generally shown in $22-41 \%$ cases with greater than 50 chromosomes being the most common in $90 \%$ of reported childhood ALL cases. Hyperdiploid stem lines with greater than 47 chromosomes are seen in $30 \%$ of children with ALL, a subset that has proved to have the most favourable prognosis. Hyperdiploidy in adult ALL likewise confers the most favourable prognosis, although the rate of treatment failure is higher than that which has been observed by children Chen (2006). Shaikh et al (2014) and Chan et al (1994) have reported a low frequency of hyperdiploidy $13.4 \%$ and $5.4 \%$ respectively. We reported High hypertriploidy (70-75 chromosomes) in three children (3.2\%), of which two cases had triploidy and Near tetraploidy is rare in childhood ALL (1\%) (Pui et al., 1990). Furthermore, the most common chromosomes gained in hyperdiploidy chromosomes 21 and marker chromosome followed by chromosomes $6,4,17,2,14,10,18,22,11$, 145,8 (Figure 2) belonged to the same pairs as reported in the literature (Raimondi et al., 1996). Hypodiploidy defines a karyotype of 35-45 chromosomes, we found 9 (9.7\%) cases with hypodiploidy of which three cases had additional structural abnormalities and chromosomal loss was most commonly seen with chromosome 9 , followed by $7,8,13$, $14,5,6$, and 18 (Figure 2). The prevalence of hypodiploidy is roughly equal among childhood and adult cases, at 5-6\% (Secker-Walker et al., 1997; Heerema et al., 1999]. Patients with 45 chromosomes are the largest hypodiploid group. Clones with 33-34 chromosomes are very rare in ALL
$(<1 \%)$. Near-haploidy is a rare group in ALL, its incidence ranging from 0.7 to $2.4 \%$ (Heerema et al., 1999). In our study patients with pseudodiploidy represented the most frequent group 36/93 (38.7\%). Pseudodiploidy is less frequent among children (18-26\%) than adults (31-50\%) (Secker-Walker et al., 1997; Heerema et al., 1999).

Structural chromosome abnormalities were observed in $44(47.3 \%)$ patients, with the overall incidence being higher in children than adults. Among the structural abnormalities observed in this study $12 \mathrm{p}$ abnormality was most frequent $(7.5 \%)$ although partial deletion of the short arm of chromosome 12 may represent $20-30 \%$ of childhood cases when loss of heterozygosity and FISH studies are applied (Stegmaier et al., 1995), conventional cytogenetic analysis documented $12 \mathrm{p}$ abnormalities in only $10 \%$ of the childhood cases and in 4-5\% of adult cases (SeckerWalker et al., 1997; Braekeleer et al., 2010). Seven patients showed $12 \mathrm{p}$ abnormalities, four in the form of deletion at breakpoints p11,p12 and three in the form of translocation with break points at $12 \mathrm{p} 12$ and $12 \mathrm{p} 13$. Interpretation of present findings is difficult, because only a subset of our patients followed up with FISH analysis using the LSI ETV6/RUNX1 extra-signal dual-colour probe. The true frequency of del $(12 p)$ is presumably underestimated.

We observed $\mathrm{t}(12 ; 21)$ in $5.4 \%$ of our patients of <8years old children still alive with B-lineage leukaemia having good prognosis. Only recently has this translocation, $\mathrm{t}(12 ; 21)(\mathrm{p} 13.3 ; \mathrm{q} 22)$, has been shown to be the most frequent, but cytogenetically largely undetected chromosomal anomaly in childhood ALL, occurring in $25-30 \%$ patients (Douet-Guilbert et al., 2003). The $t(12 ; 21)$ results in fusion of two genes: ETV6 on 12p and RUNX1 on 21q. Only ETV6/RUNX1 may play a key role in leukemogenesis (Chen, 2006; Al-Shehhi et al, 2013). This translocation defines a distinct entity of childhood pre-B ALL with a favourable prognosis (Heerema et al, 1999). Bojwani et al (2012) in their study produced significantly better outcomes and demonstrated that nearly all children with ETV6-RUNX1 ALL can be cured and Zafar Iqbal (2014) in his molecular genetic studies on pediatric ALL patients from different areas confirmed a low frequency of the favourable prognosis fusion oncogene $t(12 ; 21)$ in underdeveloped countries.

We found an incidence of $3.2 \%$ for $9 p$ abnormalities, reported as a poor prognostic factor (Heerema et al., 1999). Although their detection methodology depended on FISH, Woo et al 2005 reported 9p abnormalities as the most common in their study, emphasizing the need for a large cohort study of $9 p$ abnormalities and its clinical implications in paediatric population which is very important to present the poor prognosis cases.

The present results showed $5.4 \%$ patients with KMT2A gene rearrangement which includes both 11q23 deletion and $\mathrm{t}(4 ; 11)$ rearrangement. Chromosomal rearrangements involving the KMT2A gene are associated with ALL in infants ( $<1$ year of age), accounting for as high as $85 \%$ of the cases De Braekeleer (2005). The incidence is lower in older children and adults $(<10 \%)$ (Fenaux et al., 1989). Among the translocations involving KMT2A, the $\mathrm{t}(4 ; 11)$ rearrangement is the most common, accounting for $60 \%$ of infant cases, but is rarely observed in adult patients (Harrison et al., 2005), even we found one 54 year old 
female adult with the same translocation.

The $t(9 ; 22)(q 34.1 ; q 11.2)$ recurrent rearrangement, giving rise to the Philadelphia chromosome, is observed in about 2 to $5 \%$ of children (Moorman et al.,2007) compared with about $30 \%$ of adults (Moorman et al., 2010). Similar results were obtained in this study with $4.3 \%$ i.e. in one child and three adult ALL patients having ABL/BCR fusion. The highest reported frequency (44.5\%) of BCR-ABL Fusion oncogene in paediatric ALL, associated with poor overall survival was observed (Awan et al., 2012).

The $\mathrm{t}(1 ; 19)(\mathrm{q} 23 ; \mathrm{p} 13)$ rearrangement is a rare but recurrent abnormality; incidence is higher among children than adults, a tendency already reported in the literature (Kebriaei et al., 2003; Mroz'ek, 2004). All three cases $(3.2 \%)$ with $\mathrm{t}(1 ; 19)$ in our series had B or precursor B cell type with L1 morphology (one case with 6q- additional abnormality and another case with ish der(19)t(1;19) (ANGPTL1+ABL2+). Probe LSI 1p36/1q25 is showing two chromosomes 1 with both signals 1 p36 \& 1q25, der 19 showing fluorescent signal for 1q25 locus) which confirms a strong association between $\mathrm{t}(1 ; 19)$ and pre-B ALL as it has been reported by Fenaux et al (1989).

Deletions of the long arm of chromosome 6 occur 5-10\% of childhood and adult ALL (Heerema et al., 2000), we found only $3.2 \%$ of patients with deletion $6 \mathrm{q} 21$-ter. In approximately two thirds of the cases, $6 \mathrm{q}$ deletions are associated with other structural or numerical abnormalities, it has been described that a minimal deleted interval in 6q21 encompasses the FOXO3A, PRDM1 and HACE1 candidate genes (Thelander et al., 2008).

Translocations involving 8q24 breakpoint induce MYC dysregulation through juxtaposition with immunoglobulin gene regulatory elements on chromosomes 14 (IGH), 2 (IGK) and 22 (IGL) (Kebriaei et al., 2003). In our study we identified only three cases $(3.2 \%)$ with $\mathrm{t}(8 ; 14)$, FISH analysis of these cases were MYC and BCL6 positive, of three patients one died and two are in remission having good prognosis, but it was recently demonstrated that the use of short- term chemotherapy has significantly improved the clinical outcome (Moorman et al., 2007). Apart from these three $\mathrm{t}(8 ; 14) \mathrm{T}$-ALL's, in this report we are presenting one case with $\mathrm{t}(11 ; 14)(\mathrm{p} 13 ; \mathrm{q} 11), \mathrm{MCL} ; \mathrm{IGH} / \mathrm{BCL}-1$, one of the cytogenetic marker for ALL T Cell type.

Diagnosing ALL is a multistep process, a team work, in which clinical, morphological, cytochemical, immunophenotypical, cytogenetic and molecular investigation, bring together valuable information for a precise diagnostic conclusion. These methods are complementary rather than competitive and offer a flexible approach to diagnosis.

Regardless of specificity and nature of molecular changes seen in various neoplastic conditions, cytogenetic changes will continue to offer useful information to the clinicians in the diagnosis, prognosis and care of patients. The development of FISH has allowed the identification of cryptic abnormalities and the detection of alterations in patients with poor morphology chromosomes / no metaphases, normal, complex, or ill-defined chromosomes under conventional cytogenetics. These cytogenetic and FISH findings in ALL patients provide a useful data for prognostic and therapeutic choice. This study has confirmed the heterogeneity of ALL by identifying the various recurrent chromosomal aberrations and their association with specific immunophenotypes and FISH diagnosis. Further accumulation of these data is needed because the geographical distribution and ethnic difference of cytogenetic characterization are still uncertain.

During the last few years, analysis of ALL samples with DNA arrays has facilitated the recognition of molecularly distinct leukemia groups, the introduction of microarray gene expression profiling has opened the opportunity for accelerated progress in the diagnosis and therapy of ALL and this technique also could lead to the identification of new recurring cryptic abnormalities of prognostic significance.

\section{Acknowledgements}

We thank Ms. Hind Al Hassani for her technical support.

\section{References}

Al-Bahar, Zamecnikova A, Pandita R (2010). Frequency and type of chromosomal abnormalities in childhood acute lymphoblastic leukemia patients in kuwait:a six-year retrospective study. Med Princ Pract, 19, 176-81.

Al-Shehhi H, Konn ZJ, Schwab CJ, et al (2013). Abnormalities of the der(12)t(12;21) in ETV6-RUNX1 acute lymphoblastic Leukemia. Genes Chromosomes Cancer, 52, 202-13.

Awan T, Iqbal Z, Aleem A, et al (2012). Five most common prognostically important fusion oncogenes are detected in the majority of Pakistani pediatricacute lymphoblastic leukemia patients and are strongly associated with disease biology and treatment outcome. Asian Pac J Cancer Prev, 13, 5469-75.

Bennet JM, Catovsky D, Daniel MT, et al (1976). Proposal for the classification of the acute lymphoblastic leukemias. French-American-British co-operative group. Br J Haematol, 33, 451-8.

Bhojwani D, Pei D, Sandlund JT, et al (2012). ETV6-RUNX1positive childhood acute lymphoblastic leukemia: improved outcome with contemporary therapy. Leukemia, 26, 265-70.

Chan LC, Ha SY, Ching LM, et al (1994). Cytogenetics and immunophenotypes of childhood acute lymphoblastic leukemia in Honk Kong. Cancer Genet Cytogenet, 76, 118-24.

Chang HH, Lu MY, Jou ST, Lin KH, Tien HF, Lin DT (2006). Cytogenetics in childhood acutelymphoblastic leukemia in Taiwan: a single-institutional experience. Pediatr Hematol Oncol, 23, 495-506.

Chen Z (2006). Molecular cytogenetic markers related to prognosis in hematological malignancies. World J Pediatr, 4, 252-9.

De Braekeleer M, Morel F, Le Bris MJ(2005). The MLL gene and translocations involving chromosomal band 11q23 in acute leukemia. Anticancer Res, 25, 1931-44.

De Braekeleer E (July 2010). Cytogenetics in pre-B and B-cell acute lymphoblastic leukemia: a study of 208 patients diagnosed between 1981 and 2008. Cancer Genetics and Cytogenetics volume 200 Issue, 1, 8-15.

Douet-Guilbert N, Morel F, Le Bris MJ, et al (2003). A fluorescence in situ hybridization study of TEL-AML1 fusion in B-cell acute lymphoblastic leukemia (1984-2001). Cancer Genet Cytogenet, 144, 143-7.

Fenaux P, Lai JL, Morel P, et al (1989). Cytogenetic and their prognostic value in childhood and adult acute lymphoblastic (ALL) excluding L3. Hematol Oncol, 7, 307-17

Ferrando AA, Look AT (2000). Clinical implications of recurring chromosomal and associated molecular abnormalities in acute lymphoblastic leukemia. Semin Hematol, 37, 381-95. 
Forestier E, Gustafsson G, Heideman A, et al (1997). Prognostic impact of bone marrow karyotype inchildhood acute lymphoblastic leukemia: Swedish experiences 1986-91. Acta Pediatr, 86, 819-25.

Gimidene A, Sennana H, Elgezal H, et al (2008). Cytogenetic analysis of 298 newly diagnosed cases of acute lymphoblastic leukemia in Tunisia. Hematol Oncol, 26, 91-7.

Hashem S, Mazloumi M, Madhumathi DS, Appaji L, Prasannakumari (2012). Combined study of cytogenetics and fluorescence in situ hybridization (FISH) analysis in childhood acute lymphoblastic leukemia (ALL) in a Tertiary cancer centre in South India. Asian Pacific J Cancer Prev, 13, 3825-27.

Harrison CJ (2001). The detection and significance of chromosomal abnormalities in childhood acute lymphoblastic leukemia. Blood Rev, 15, 49-59.

Harrison CJ, Faroni L (2002). Cytogenetic and molecular genetics of acute lymphoblastic leukemia. Rev Clin Exp Hematol, 6 , 91-113.

Harrison CJ, Moorman AV, Barber KE, et al (2005). Interphase molecular cytogenetic screening for chromosomal abnormalities of prognostic significance in childhood acute lymphoblastic leukaemia: a UK Cancer Cytogenetics Group Study. Br J Haematol, 129, 520-30.

Heerema NA, Nachman JB, Sather HN, et al (1999). Hypodiploidy with less than 45 chromosomes confers adverse risk in childhood acute lymphoblastic leukemia: a report from the children's cancer group. Blood, 94, 4036-45.

Heerema NA, Sather HN, Sensel MG, et al (1999). Association of chromosome arm 9p abnormalities with adverse risk in childhood acute lymphoblastic leukemia: a report from children's cancer group. Blood, 94, 1537-44.

Heerema NA, Sather HN, Sensel MG, et al (2000). Clinical significance of deletions of chromosome $6 \mathrm{q}$ in childhood acute lymphoblastic leukemia: a report from the children's cancer group. Leuk Lymphoma, 36, 467-78.

$\mathrm{Hu} \mathrm{L}$, Ru K, Zhang L, et al (2014). Fluorescence in situ hybridization (FISH): an increasingly demanded tool for biomarker research and personalized medicine. Biomarker Research. 2,3.

ISCN 2013 In: An International System for Human Cytogenetic Nomenclature.

Mitelman F, editors. Basel, Switzerland: S. Karger.

Jennigs CD, Foon KA (1997). Recent advances in flow cytometry:application to the diagnosis of hematologic malignancy. Blood, 90, 2863-92.

Johansson B (2009). High hyperdiploid childhood acute lymphoblastic leukemia. Genes Chromosomes Cancer, $\mathbf{4 8}$, 637-60.

Kebriaei P, AnastasiJ, Larson RA (2003). Acute lymphoblastic leukemia: diagnosis and classification. Best Pract Res Clin Haematol, 15, 597-621.

Kwon YJ, Lee JW, Kim MS, et al (2009). Cytogenetic analysis in childhood acute lymphoblastic leukemia: experience at a single institution in Korea. Int J Hematol, 89, 150-8.

Mehdipour P, Mirfakhraie R, Jahani M, et al (2003). Karyotypic evolution: cytogenetics follow-up study in childhood acute lymphoblastic leukemia. Asian Pac J Cancer Prev, 4, 358-68.

Moorman AV, Harrison CJ, Buck GA, et al (2007). Karyotype is an independent prognostic factor in adult acute lymphoblastic leukemia (ALL): analysis of cytogenetic data from patients treated on the medical research council (MRC) UKALLXII/ eastern cooperative oncology group (ECOG) 2993 trial. Blood, 109, 3189-97.

Moorman AV, Chilton L, Wilkinson J, et al (2010). A populationbased cytogenetic study of adults with acute lymphoblastic leukemia. Blood, 115, 206-14.

Mroz'ek K, Heerema NA, Bloomfield CD (2004). Cytogenetics in acute leukemia. Blood Rev, 18, 115-36.

NordgrenA, Heyman M, Sahlen S, et al (2002). Spectralkaryotyping and interphase FISH reveal abnormalities not detected by conventional G-banding. Implications for treatment stratification of childhood acute lymphoblastic leukaemia: detailed analysis of 70 cases. Eur J Haematol, 68, 31-41.

Perez-Vera P, Muzica-Sanchez M, Carnevale A, et al (2001). Cytogenetics in acute lymphoblastic leukemia in mexican children: an institutional experience. Arch Med Res, 32, 202-07.

Petkovic I, Josip K, Nakic M, Kastelan M (1996). Cytogenetic, cytomorphologic and immunologic analysis in 55 children with acute lymphoblastic leukemia: Cancer Genet Cytogenet, 88, 57-65.

Pui CH, Carroll AJ, Head D, et al (1990). Near-triploid and Near-tetraploid acute lymphoblastic leukemia of childhood. Blood, 76, 590-6.

Pui CH, Relling MV, Downing JR(2004). Acute lymphoblastic leukemia. N Engl J Med, 350, 1535-48.

Raimondi SC, Pui CH, Hancock ML, et al (1996). Heterogeneity of hyperdiploid (51-67) childhood acute lymphoblastic leukemia. Leukemia, 10, 213-24.

Romana SP, Le Coniat M, Berger R (1994). t(12;21): A new recurrent translocation in acute lymphoblastic leukemia. Genes Chromosomes Cancer, 9, 186-91.

Sabir N, Iqbal Z, Aleem A, Awan T, et al (2012). Prognostically significant fusion oncogenes in pakistani patients with adult acute lymphoblastic leukemia and their association with disease biology and outcome. Asian Pac J Cancer Prev, 13, 3349-55.

Secker-Walker LM, Prentice HG, Durrant J, et al (1997). MRC adult leukemia working party: cytogenetics adds independent prognostic information in adults with acute lymphoblastic leukemia on MRC trial UKALL XA. Br J Haematol, 96, 601-10.

Salem DA, Abd El-Aziz SM (2012). Flowcytometric immunophenotypic profile of acute leukemia: mansoure experience. Indian J Hematol Blood Transfus, 28, 89-96.

Shaikh MS, Ali SS, Khurshid M, Fadoo Z (2014). Chromosomal abnormalities in Pakistani children with acute lymphoblastic leukemia. Asian Pac J Cancer Prev, 15, 3907-09.

Simons A, Stevens-Kroef M, Idrissi-Zaynoun, NE, et al (2011). Microarray-based genomic profiling as a diagnostic tool in acute lymphoblastic leukemia. Genes Chromosome Cancer, 50, 969-81.

Spathas DH, Stewart J, Singer IO, et al (1999). Detection of $\mathrm{t}(12 ; 21)$ in childhood acute lymphoblastic leukemia by fluorescence in situ hybridization. Cancer Genet Cytogenet, 110, 7-13

Stegmaier K, Pendse S, Barker GF, et al (1995). Frequent loss of heterozygosityat the TEL gene locus in acute lymphoblastic leukemia of childhood. Blood, 86, 38-44.

Thelander EF, Ichimura K, Corcoran M, et al (2008). Characterization of $6 \mathrm{q}$ deletions in mature $\mathrm{B}$ cell lymphomas and childhood acute lymphoblastic leukemia. Leuk Lymphoma, 49, 477-87.

Woo HY, Kim DW, Park H, et al (2005). Molecular cytogenetic analysis of gene rearrangements in childhood pediatric acute lymphoblastic leukemia. J Korean Med Sci, 20, 36-41.

Zafar Iqbal (2014). Molecular genetic studies on 167 pediatric all patients from different areas of pakistan confirm a low frequency of the favorable prognosis fusion oncogene TELAML1 $\mathrm{t}(12 ; 21)$ in underdeveloped countries of the region. Asian Pac J Cancer Prev, 15, 3541-46.

Zakaria Z, Md Ahid MF, Ismail A, et al (2012). Chromosomal aberrations in ETV6/RUNX1-positive childhood acute lymphoblastic leukemia using $244 \mathrm{~K}$ oligonucleotide array comparative genomic hybridization. Mol Cytogenet, 5, 41 . 